Review Article

\title{
Mycorrhizae Aided Nitrogen Nutrition and Drought Tolerance in Plants \\ Subramanian $\mathrm{K} \mathrm{S}^{1 *}$, Praghadeesh $\mathbf{M}^{2}$, Balakrishnan $\mathrm{N}^{2}$, Rajkishore $\mathbf{S ~ K}^{2}$ and Nandakumar $\mathrm{N} \mathrm{B}^{3}$ \\ 1.Tamil Nadu Agricultural University, Coimbatore-641 003 \\ 2.Department of Nano Science and Technology, Tamil Nadu Agricultural University, Coimbatore-641 003 \\ ${ }^{3}$ Water Technology Centre, Tamil Nadu Agricultural University, Coimbatore-641 003
}

\begin{abstract}
Mycorrhizas are known to improve host plant nutritional status as a consequence of water transport from the soil to the host plant through the external mycelium as a direct effect or improved host plant nutrition primarily, phosphorus as an indirect effect. The direct hyphal water transport is quantified to be meager and a major part of the benefits of mycorrhizal symbiosis is indirect and nutritionally related. In arid and semi-arid regions where drought occurrence is very frequent and soil moisture content is highly restricted, mycorrhizas can assist in exploiting the soil beyond the rhizosphere that helps the host plant to withstand drought stress conditions. The drought tolerance in mycorrhiza-inoculated plants is quite complex and such response is due to a series of processes such as improved nitrogen (N) availability in soils, extensive root surface area and cationic exchange capacity, collective $\mathrm{N}$ assimilatory pathways in plant-mycorrhizal system, luxuriant uptake of nutrients besides remobilization of nutrients to support grain growth. These physiological, biochemical, nutritional and morphological changes in the mycorrhizas associated host plants have contributed to the ability of the host plants to survive under limited water environments. Despite mycorrhiza-assisted and $\mathrm{N}$ nutritionally enabled host plant drought tolerance is evident, more research is required to gain insights into the mechanisms involved. This review highlights the role of mycorrhizas on $\mathrm{N}$ dynamics in the rhizosphere and enhanced host plant $\mathrm{N}$ nutrition that collectively contributes to the sustained crop productivity under drought stress conditions.
\end{abstract}

Keywords: Mycorrhiza; Arbuscular mycorrhizal fungi; Drought; Stress tolerance; N Nutrition

\section{INTRODUCTION}

Drought stress in arid and semi-arid regions is quite common where the abiotic stress limits plant growth and reduces crop production across the globe. Globally, more than $30 \%$ of arable soils are exposed to drought stress inhibiting normal plant growth and development (Calvo-Polanco et al., 2016). Many factors encompassing deficit rainfall erratic distribution of precipitation, intensity and duration of drought are eventually resulting in water scarcity (Kolenc et al., 2016). Drought stress causes lower soil water potential that commensurate with plant responses such as cell dehydration, reduced cell expansion and division, restricted leaf size, stem elongation, root proliferation, plant water status, nutrient uptake, and water use efficiency (Kaushal and Wani, 2016). To overcome these maladies, plants get adapted to drought stress conditions by modifying the morphological, physiological, and biochemical attributes that lead the plants to escape or avoid or sustain drought stress conditions (Khoyerdi et al., 2016).

Water deficit in arid and semi-arid environments is considered as major abiotic stress that drastically reduced the plant growth parameters regardless of regions across the globe (Kramer and Boyer, 1995; Cattivelli et al., 2008; Lambers et al., 2008; Trenberth et al., 2014). However, the impacts of drought stress will be more pronounced in arid and semi-arid areas where the potential evapo-transpiration exceeds the precipitation (Knapp et al., 2001; Seki et al., 2003; Fischlin et al., 2007). Drought stress in conjunction with rising average temperatures causes a further raise in evapotranspiration rates while reducing the water storage in soils (Wery et al., 1994; RaptiCaputo, 2010).

One of the natural ways to mitigate drought stress is by exploiting arbuscular mycorrhizal fungal (AMF) symbiosis. The AMF colonization is known to improve host plant resilience to environmental 
stresses such as high temperature (Zhu et al., 2010; Maya and Matsubara, 2013), drought (Augé, 2001; Querejeta et al., 2006; Subramanian et al., 2006), salt stress(Ruiz-Lozano et al., 2012; Estrada et al., 2013; Hajiboland, 2013), metal toxicity (Forgy, 2012), soil compaction (Miransari, 2013) besides biotic stresses (Jung et al., 2012; Nadeem et al., 2014). Among the abiotic stresses, drought is one of the most severe one and mycorrhizal symbiosis is widely believed to support plant growth in inhospitable weather conditions. The insights of host plant drought tolerance include improved nutritional status, enhanced osmotic adjustment and increased antioxidant production besides protective molecules (Ortiz et al., 2015).

Several studies have proved beyond doubt that the microbes improve plant tolerance to abiotic stresses by facilitating moisture and nutrient absorption. Nitrogen-fixing bacteria and arbuscular mycorrhizal fungi (AMF) are of global significance in inducing drought tolerance in host plants(Subramanian and Charest, 1995; 1997; Augé, 2001; Barea et al., 2005; Hidri et al., 2016). The AMF symbiosis improves drought tolerance of the host plants as a direct (water uptake) and indirect effects associated with improved host plant nutrition, particularly phosphorous. The phosphate ions are highly immobile and their movement hardly exceeds $1 \mathrm{~mm}$ for every 24 hours. Such mobility is further restricted under drought stress conditions. Under these circumstances, AMF inoculated plants have access to use the $P$, which is rarely available to non-inoculated ones. It has been unequivocally demonstrated that AMF inoculation facilitates scavenging of large soil volume beyond the rhizosphere, which assists in $\mathrm{P}$ nutrition and drought tolerance of AMF-inoculated maize plants (Subramanian and Charest, 1997). The majority of abiotic stress tolerance of host plants is closely associated with increased nutrient absorption, enhanced photosynthetic activity, accumulation of organic and inorganic osmolytes production of antioxidants, and altered rhizosphere (Barzana et al., 2015; Calvo-Polanco et al., 2016; Yin et al., 2016). Even though the AMF symbiosis helps the host plants to sustain a wide array of edapho-climatic stress conditions, the mycorrhizal response is more significant under low input agricultural production systems and the response increases with increasing intensity of drought stress conditions (Sylvia et al., 1993; Subramanian et al., 2006). Mycorrhiza-aided drought tolerance of host plants has been widely reviewed for the past several decades (Fitter, 1985; Read and Boyd, 1986; Nelsen, 1987; Gupta and Janardhanan, 1991; Koide, 1993; Sanchez-Diaz and Honrubia, 1994; Augé, 2001; Subramanian and Charest, 2007; Smith and Smith, 2011). The major part of the reviews, evolved a widely accepted hypothesis is that AMF symbiosis assists in $P$ nutrition which eventually resulted in host plant drought tolerance. Although nutritionally aided host plant drought tolerance is well established beyond doubt, the relationship between $\mathrm{N}$ nutrition and host plant to sustain drought conditions is poorly understood. This review provides a new dimension to the role of AMF in improving drought tolerance as a consequence of $\mathrm{N}$ nutrition.

\section{Role of $A M$ fungi for $\mathbf{N}$ nutrition}

A major part of the soil $\mathrm{N}$ is present in organic form and a fraction of $\mathrm{N}$ as $\mathrm{NO}_{3}$ - and $\mathrm{NH}_{4}{ }^{+}$forms. Most of the terrestrial plants take up $\mathrm{N}$ in the nitrate form and few plants in wetlands, including rice, utilize $\mathrm{NH}_{4}-\mathrm{N}$ form. It is well established that nitrates are the major form of $\mathrm{N}$ in many of the arable soils. Nitrate is mobile in well-watered conditions where the role of AMF in such soils is least significant (Harley, 1989; Barea et al., 2005). However, $\mathrm{NO}_{3}$. mobility is highly restricted under water deficit conditions due to impeded mass flow and diffusion. Under such circumstances, mycorrhizas may play a vital role in nitrate transport to the root surface. The mycorrhiza is believed to increase the soil $\mathrm{N}$ pool size and facilitate the utilization of soil $\mathrm{N}$ by the host plants that are less available or unavailable.

Further, mycorrhiza inoculated plants can acquire $\mathrm{N}$, which is rarely available to non-mycorrhizal plants. It has been reported that the external mycelium of AMF can transport $\mathrm{NO}_{3}-\mathrm{N}$ from the soil to the root zone up to $33 \%$ under water deficit conditions (Subramanian and Charest, 1997). Consequently, the glutamine synthetase activity has increased by $28 \%$ which clearly indicated the involvement of mycorrhizas in altered $\mathrm{N}$ assimilation. The AMF hyphae can extend in the root zone beyond the rhizosphere for acquisition of slowly diffusing mineral ions such as $\mathrm{NO}_{3}$ under water deficit conditions. In addition to the acquisition of mineral ions, AMF plants have the potential to mineralize organic sources of N (Ibijbijen et al., 1996). On the other hand, others have observed that Funneliformis mosseae (formerly Glomus mosseae) Glomus mosseae colonized wheat plants showed no enhanced $\mathrm{N}$ nutrition since $\mathrm{N}$ is needed for the growth and development of hyphae and its contribution may be inadequate to meet the $\mathrm{N}$ requirements of the host plants (Hawkins and George, 1999).

Nitrogen availability in terrestrial ecosystems is highly limited and in many cases, plants depend on biogeocyling of nutrients (Clark and Zeto, 2000). The inorganic $\mathrm{N}$ forms $\left(\mathrm{NO}_{3}-\right.$ or $\left.\mathrm{NH}_{4}{ }^{+}\right)$ can transfer to their host plants (Peterson et al., 2004) either through roots directly or via diffusion and the mycorrhizal assistance in capturing inorganic $\mathrm{N}$ appears to be meager (Fukasawa et al., 
2009). However, N acquisition through mycorrhizal symbiosis may be significant to the host plant in highly competitive natural environments (Sasan and Bidochka, 2012). The AMF spores germination is facilitated by signal exchange that further promotes coordinated differentiation to establish the hyphal network in the root cortex. Plants in response to the invading mycelial mass in the root system undergo the development of new membranes, alterations in physiological condition to accommodate the deeply enriching hyphal network (MacLean et al., 2017). The phenomenon was generally ascribed as 'accommodation program' (Parniske, 2000), which is experimentally corroborated and validated with genomics and transcriptome analysis in mutant lines. Fochi et al., 2017 elucidated the genes involved in the active uptake of inorganic ammonium from the soil into the fungal system and the subsequent mobilization into the plant system through specialized transporter genes. Quantification of gene expression study involving ammonium transporter gene (TCAMT1 and TCAMT2) using qRT-PCR in orchid mycorrhiza (Tulasnella calospora) demonstrated that they harbor two sets of genes that regulate the expression of ammonium transporters which are crucial for mycorrhiza to exploit organic and inorganic nitrogen sources. In addition, the genes encoding glutamine synthetase viz., TcGS1 and TcGS2, which are the key enzymes in assimilating nitrogen in the plant system also found to be up-regulated during the mycorrhizal symbiosis and during the availability of ammonium. The AMF proliferate in the rhizosphere and assimilate inorganic $\mathrm{N}$ into organic $\mathrm{N}$ in the form of arginine and incorporate into the host plant root systems(Peterson et al., 2004). In contrast, nitrogen in soils is in complex organic form and AMF possesses no ability to degrade organic matter and thus, there is no possibility of exploiting mineralizable nitrogen. Guether et al., 2009, through gene expression studies of plant mycorrhiza dependent ammonium transporters (AMT's) and molecular modeling of AMT's with plant-based $\mathrm{NH}_{4}{ }^{+}$binding protein transporters, investigated the possibility of new ammonium and phosphate uptake interface model by accounting the seven importer cum transporters ,involved in fungal and plant continuum.

Nitrogen-deficient environment predisposes the plants to be infected with pathogens. Under such situations, mycorrhizal symbiosis aids in improving the survival of the host plants. Mycorrhizal plants are known to be quite efficient in enabling plants to adapt to varied environmental challenges. Studies have proved that the symbiosis with AMF can confer resistance against root and foliar pathogens. Tomato plants inoculated with the AMF exhibits improved resistance against Botrytis cinerea a necrotrophic foliar pathogen. Further, plants subjected to a short period of nitrogen starvation evoke metabolic and genetic responses by reprogramming at transcriptome level and prioritize abiotic stress tolerance. As a result, plants subjected to shortterm nitrogen depletion become more susceptible to B. cinerea. (Sanchez-Bell et al., 2016). Salinity interferes with nitrogen $(\mathrm{N})$ acquisition and utilization by influencing different stages of $\mathrm{N}$ metabolism, such as $\mathrm{NO}_{3}$ uptake, reduction and protein synthesis (Evelin et al., 2012; Aggarwal et al., 2012). AMF enhances the better assimilation of $\mathrm{N}$ by the host plants. Campanelli et al. (2013) showed that AMF mediated growth could be the result of an improvement in nitrogen status, as observed by the SPAD (Chlorophyll Meter) values monitored during a glasshouse trial. The SPAD values were closely linked to leaf chlorophyll content and leaf $\mathrm{N}$ content (Esfahani et al., 2008; Netto et al., 2005, Kumar et al., 2015).

Jin et al., (2005), with the aid of Ri T-DNA transformed carrot roots grown in vitro conditions and colonization with $\mathrm{G}$. intraradices quantified the contribution of $\mathrm{N}$ from the fungal to plant system by monitoring the dynamics of radiotracers $\left({ }^{15} \mathrm{~N}\right.$ and ${ }^{13} \mathrm{C}$ ) and amino acids using GC-MS and HPLC. The study is in agreement with that of the earlier reports that arginine is the major form of $\mathrm{N}$ synthesized and mobilized in the extra radical mycelium. These studies corroborate with our earlier reports indicating hyphal transport of nitrate nitrogen and its associated enhancement in the assimilation of nitrogen in the host plants, especially under drought conditions (Subramanian and Charest, 1999). This mechanism facilitates the host plant to sustain under water deficit environments. Despite the fact that the literature review clearly demonstrates that the role of mycorrhizal symbiosis in increasing the availability of $\mathrm{N}$ in soils is very trivial, the contribution may be significant in the context of drought conditions where nitrogen availability is very crucial for crop growth and sustaining farm productivity.

\section{Biogeocycling of nitrogen in plant-mycorrhizal system}

Microbes play a key ecological role in the sustenance and resilience of global agricultural systems. Naturally occurring symbiosis between Rhizobium and legume plants are widely believed to decrease $\mathrm{N}$ application on arable fields besides preserving the environment from eutrophication (Kiers et al., 2011). Arbuscular mycorrhizal fungi (AMF) symbiosis in terrestrial ecosystems is equally important to sustain the productivity of agricultural production systems through biogeocycling of nitrogen and carbon in plant-mycorrhizal systems.

The mutual relationship between AMF and host plant is accomplished in exchange for carbon 
from the host plant to the AMF and in turn fungusderived slowly diffusing $P$ (Hammer et al., 2011). The mycorrhizal trade synchronized with biomass gain of plants in $\mathrm{P}$ deficient or adequately $\mathrm{P}$ nourished soil(Subramanian et al., 2008). Though the root organ culture experiments have shown a bidirectional exchange of $\mathrm{C}$ and $\mathrm{N}$ between $\mathrm{AMF}$ and plant, there was no gain in fungal biomass(Fellbaum et al., 2012). It is observed that $\mathrm{N}$ exchange between plants and fungi in $\mathrm{N}$ deficit environments did not exhibit bilateral exchange of nutrients while fungal biomass gain was obvious under $P$ limited conditions(Smith and Smith, 2011). The soil N status may influence AMF indirectly by altering the $\mathrm{C}$ dynamics in plant-mycorrhizal systems. One of the key enzymes in photosynthesis is RuBisCo which is a rate-limiting enzyme closely related to leaf $\mathrm{N}$ (Chapin et al., 1987). Consequently, N nutrition has a strong influence on the photosynthetic capacity of plants that enable trading off $\mathrm{C}$ with mycorrhizal fungi. In other studies, the data have shown that mycorrhizal symbiosis assists in enhanced $\mathrm{N}$ assimilating enzymes and $\mathrm{N}$ compounds that enable the host plant to survive under water deficit conditions (Subramanian and Charest, 1998). Further, AMF is influenced by $\mathrm{N}$ availability due to the fungal tissues assimilating $\mathrm{N}$ in the form of amino acids or as polymeric N(Blackwell, 1988). Therefore, soil $\mathrm{N}$ availability modifies both the photosynthetic rates of plants nourished with adequate $\mathrm{N}$ and the $\mathrm{C}$ requirement of the fungus under the deficient level of N. Hodge and Storer, 2015 described the N uptake and transfer from mycorrhizal system and plants under arrays of experimental conditions ( $\mathrm{N}$ availability) and their interaction with carbon (C) uptake. The study focused on $\mathrm{N}$ mobilization in the presence of organic and inorganic $\mathrm{N}$ sources using dual labeled stable isotopes $\left({ }^{15} \mathrm{~N}\right.$ and $\left.{ }^{13} \mathrm{C}\right)$, under compartmental microcosm units. The hyphal length and density were found to be significantly higher organic patches. Further, the competitive interaction of other microflora in the ecosystem is majorly driven by the availability of $\mathrm{N}$ and $\mathrm{C}$ resources. The uptake of $\mathrm{N}$ is indirectly dictated by the availability and mineralization of $\mathrm{C}$ to the fungal system. The authors found that even a minute increment of available $\mathrm{C}$ will substantially increase the mineralization rate (Hodge and Storer, 2015).

Veresoglou et al., 2012, briefly summarized the potential pathways that could mediate or alter the biogeocycling of $\mathrm{N}$ viz., substrate availability, abiotic soil environment, shift in microflora community and status of individual host plant nutrition level. Several studies have clearly shown that ectomycorrhizal association assists in $\mathrm{N}$ assimilation in natural forest ecosystems and acquisition and assimilation vary widely with the fungal species and host plants(Vézina et al., 1989; Chalot et al., 1994). On the other hand, very few studies have demonstrated that AMF alters the $\mathrm{N}$ assimilation of host plants. Tracer studies have shown that the external hyphae of the AMF facilitate the transfer of slowly diffusing forms of $\mathrm{NH}_{4}-\mathrm{N}$ and $\mathrm{NO}_{3}-\mathrm{N}$ under drought conditions (Frey and Schüepp, 1993; Tobar et al., 1994a; Tobar et al., 1994b; Subramanian and Charest, 1999). Hodge and Fitter, 2010 have demonstrated that the transfer of organic $\mathrm{N}$ from the soil to the fungus commensurate with the requirements of both the host plant (Plantago lanceolata) and the fungus (G. hoi and G. mosseae). The study also documented that the extensive and aggressive proliferation of AMF fungal biomass in the presence of organic $\mathrm{N}$ patches using compartmented microcosm units. The earlier reports indicated that AMF spores were found to have genes coding for nitrate reductase (Ho and Trappe, 1975) and genetic evidence of possessing $\mathrm{N}$ assimilatory enzymes (Kaldorf and Ludwig-Müller, 2000). These reports served as a base to support the hypothesis that AMF assists in the $\mathrm{N}$ assimilation pathway and its role is significant, especially under drought stress conditions where $\mathrm{NO}_{3}^{-}$mobility is impeded and the transfer of metabolites from the fungus enables host plant drought tolerance.

The AMF responds to external $\mathrm{N}$ inputs in both temperate and tropical forests with strong declines in root colonization, spore density, and external hyphal length, particularly in soils with initially low $\mathrm{N}: \mathrm{P}$ where $\mathrm{N}$ deposition causes both $\mathrm{N}$ and $\mathrm{P}$ to be in high supply. (Sheldrake et al., 2018). Lilleskov et al., (2018) summarized the differential response of AMF and Ectomycorrhizal fungi (EcMF) to the external input of $\mathrm{N}$. The complexity involved in the traceability of $\mathrm{N}$ Mobilization often overshadowed the absolute quantification of $\mathrm{N}$ movement in plant - AMF network in contrast to the plant - EcMF.

\section{Hyphal transport of nitrogen leading to host plant drought tolerance}

One of the critical nutrients deciding the fate of agricultural productivity under drought stress conditions is nitrogen. Host plant $\mathrm{N}$ nutrition is often as a result of either direct transfer of $\mathrm{N}$ through the extraradical mycelial network or indirect transfer involving leakage of nitrogen from the root, its absorption by AMF hyphae scavenging in the rhizosphere, and transfers it to the host plants. Further, there is a greater ability of the mycorrhizal plants to absorb nutrients directly from the soil. Among these three mechanisms, direct $\mathrm{N}$ transfer is considered unique and significant in the plantmycorrhizal system. Over the years, hyphal transport of $\mathrm{N}$ has been quantified using a compartmental box system (Frey and Schüepp, 1993; Tobar et al., 1994a; Tobar et al., 1994b; Subramanian and Charest, 1999).

$107 \mid 10-12$ | 4 
In fact, the external mycelium of AMF can transport both forms of $\mathrm{N}$ simultaneously. However, $\mathrm{NH}_{4}-\mathrm{N}$ acquisition by AMF colonized plants is considered significant as $\mathrm{NH}_{4}-\mathrm{N}$ has lower mobility in the soil in comparison to $\mathrm{NO}_{3}-\mathrm{N}$ (Azcón-Aguilar and Barea, 1997). The acquisition and hyphal transport of both $\mathrm{NH}_{4}-\mathrm{N}$ and $\mathrm{NO}_{3}-\mathrm{N}$ may readily occur in $\mathrm{AM}$ plants (Bowen and Smith, 1981; Bago et al., 1998; Subramanian and Charest, 1999). The hyphae enable the transport of $\mathrm{N}$ from soil to roots (George et al., 1992; Johansen et al., 1992; Bago et al., 2002). To quantify the hyphal transport of $N$ by separating the hyphae from root acquisition using an elegant compartmented box system(Kothari et al., 1990; Faber et al., 1991). Nylon mesh with a pore dimension of $45 \mu \mathrm{m}$ is placed to allow the external mycelium to proliferate while impeding the roots. This enables us to detect the amount of $\mathrm{N}$ being transported through extra-radical mycelium $\left({ }^{15} \mathrm{~N}\right.$ studies) and accumulation in host plants.

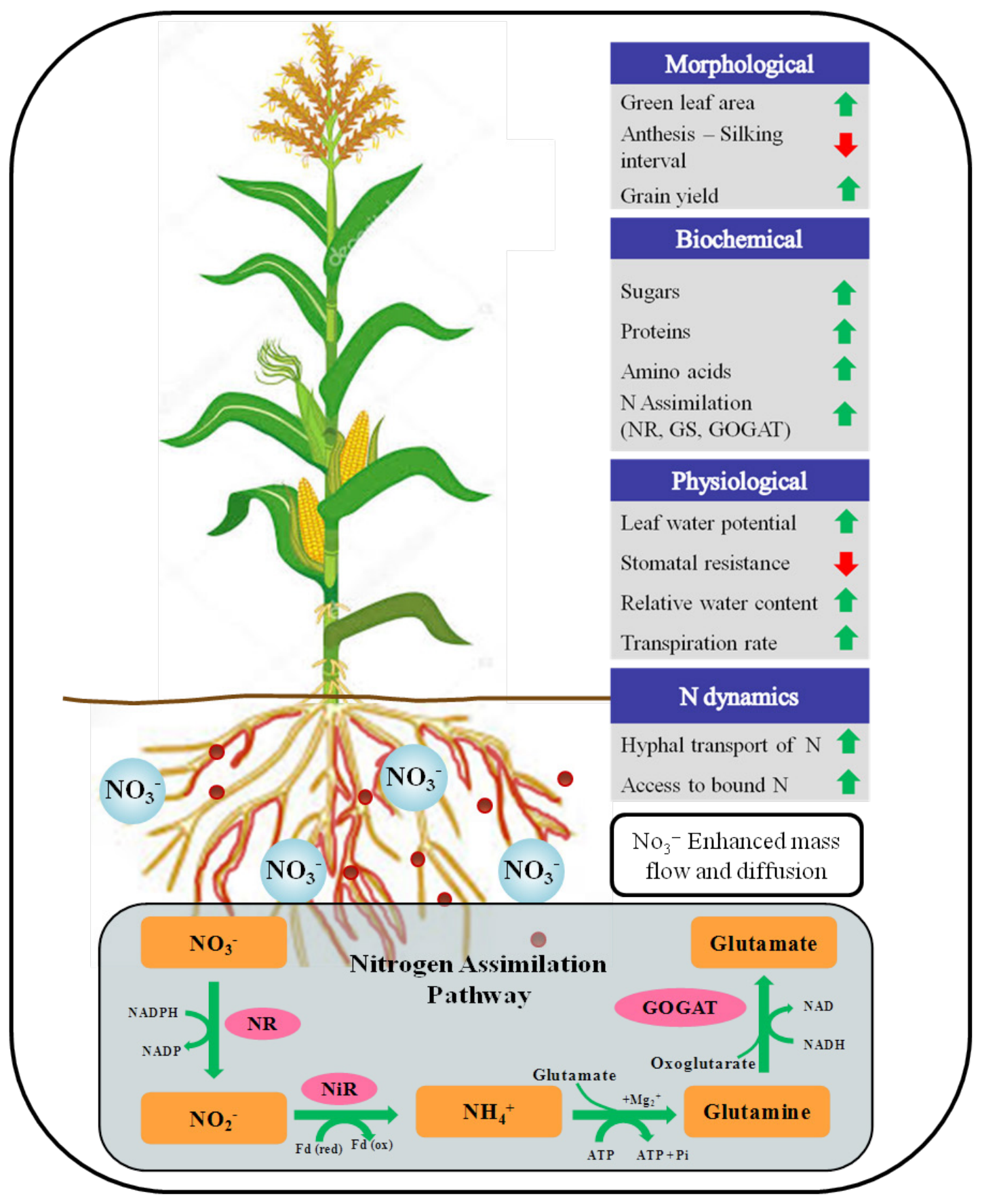

Figure.1. Mechanisms involved in mycorrzhizae-aided drought tolerance in the host plant. (Morphological, Biochemical and Physiological changes in AM colonized plants under drought conditions are summarised. The arrows within a box represent changes in the mycorrhizal plants i.e. increase (up) or decrease (down) in comparison to the non-mycorrhizal plants.) 
The acquisition of $\mathrm{N}$ by the mycorrhizal fungi may differ with the diversity of isolates. Frey and Schuepp (1993) have shown enhancement of nitrogen concentration in maize plants differed in the descending order of various mycorrhizal species Gi. margarita $>$ G. intraradices $>A$. laevis. AMF Maize plants had higher uptake and transport of $\mathrm{N}$ as a direct consequence of hyphae spread in soil (Frey and Schüepp, 1993).

Further, Cruz et al., 2007 studied the dynamics of $\mathrm{NH}_{4}{ }^{+}$uptake, synthesis of arginine (Arg) and its translocation through extra radical mycelium followed by subsequent catabolism of arginine into inorganic form in intra radical mycelium in order to effect transfer of $\mathrm{NH}_{4}{ }^{+}$into plant system. Even the minute degree of changes in the $\mathrm{NH}_{4}{ }^{+}$was documented using ${ }^{15} \mathrm{~N}$ - labeling studies and enzyme assays (glutamine synthetase (GS), argininosuccinate synthetase (ASS), arginase and urease activities). The results revealed that (GS) activity was crucial and independent of the amount and availability of $\mathrm{NH} 4+$ for assimilation. The activity is reported to be more pronounced during nitrogen starvation when compared to treatments that are supplied with exogenous nitrogen. (Cruz et al., 2007)

These reviews have demonstrated that the extra-radical mycelium of AMF played a vital role in $\mathrm{NO}_{3}$ transport under limited water conditions (Subramanian and Charest, 1999). The excess N cycled through the mycorrhizal system improved the host plant nutritional status and glutamine synthetase (GS) activity. The nitrate transported by the external mycelium induced the nitrate reductase (NR) activities and GS-GOGAT cycle (Subramanian and Charest, 1998). Since NR is a substrate inducible enzyme, it triggers key enzymes involved in $\mathrm{N}$ assimilatory pathway. The improved $\mathrm{N}$ acquisition and assimilation may assist the host plant in overcoming moderate to severe drought stress conditions. The movement of $\mathrm{NO}_{3}{ }^{-}$ions is highly impeded under a limited water environment due to low concentration and diffusion rates(Azcón et al., 2008). Under such conditions, the ${ }^{15} \mathrm{~N}$ in plant tissues derived from the tagged nitrogenous fertilizer was higher by $33 \%$ in AMF colonized roots than their non-colonized roots. These literature demonstrate that the extra-radical mycelium plays a pivotal role in uptake and translocation of $\mathrm{NO}_{3}$ ions especially under drought conditions.

Further, the external mycelium in soil undergoes degradation that assists in retaining soil moisture, which is closely associated with the formation of water-stable soil aggregates (Schreiner, 2003). This also regulates the retention and release of $N$ from the rhizosphere. Druge and Schonbeck (1993) reported that the hyphal network in the root zone of AM flax (Linum usitatissimum L.) plants was more intense, which enhances the moisture retention and release characteristics of the soil (Drüge and Schonbeck, 1993).

There is a tripartite association among cereal - legume - mycorrhiza wherein nitrogen from AM legumes is transferred to non-legumes (grasses) through external mycelium. Such associations are $\mathrm{N}$ transfer from clover to ryegrass (Haystead et al., 1988), soybean to maize (van Kessel et al., 1985; Bethlenfalvay et al., 1996), bean to maize (Martins and Cruz, 1998), alfalfa to ryegrass (Barea et al., 1989) and maize to soybean (Subramanian et al., 2011). The co-inoculation of Rhizobium and AMF increased nutritional, biochemical and enzymatic characteristics that increased soybean yield by $10-25 \%$ besides maintaining soil fertility. Further, $\mathrm{P}$ transfer from AMF plants to other plants has also been reported (Heap and Newman, 1980; Newman and Ritz, 1986). The transfer of $\mathrm{N}$ between legumes and cereal is very significant in the context of the cycling of nutrients and its associated impacts on drought tolerance of the host plants.

\section{Physiology of Mycorrhizal Plants}

The AMF improves plant-water relations as a consequence of several inter-linking mechanisms (Augé, 2001). The external mycelium can penetrate soil pores that are inaccessible to root hairs and exploit moisture absorption to support plant growth (Allen, 1982; Hardie, 1985; Marulanda et al., 2003). The hyphal transport of water to the root varies widely from $0.1 \mu \mathrm{Lh}-1$ per hyphal entry point (Allen, 1982) and up to $0.76 \mu \mathrm{Lh}-1$ per hyphae (Faber et al., 1991). Plants associated with a wide range of AMF species have received a flow of 3 to $4.75 \mathrm{~mL}$ $\mathrm{H}_{2} \mathrm{O}$ plant-1 day-1 greater than non-colonized plants; in turn, it enhances the water uptake by plants (Marulanda et al., 2003). Ruiz-Lozano and Azcón (1995) have shown water uptake by AM colonized Lactuca sativa, but the quantity appears to be negligible. The mycelia of AMF differed in their influence on water uptake, despite similar mycelium length (Ruiz-Lozano and Azcón, 1995).

The AMF colonized maize plants had maintained higher (less negative) leaf water potential (LWP), transpiration rate and lower stomatal resistance during the three weeks of drought stress than uninoculated counterparts (Subramanian and Charest, 1995). Such favorable physiological activities assist in the retention of larger green leaf areas under moderate drought stress conditions. On rewatering, the drought-stressed AMF plants recovered faster within a week, while uninoculated plants took three weeks to regain their water status (Subramanian and Charest, 1997). The leaf water potential of maize plants were continued to be higher (less negative) even after 21 days of drought

$107 \mid 10-12$ | 6 
exposure which closely coincided with the improved nutrition of slowly diffusing mineral ions such as phosphates, $\mathrm{Zn}, \mathrm{Cu}$, and nitrates that facilitate the host plant to take up water more efficiently under drought conditions (Sylvia et al., 1993; Tobar et al., 1994a; Tobar et al., 1994b; Subramanian and Charest, 1997). The maintenance of leaf moisture status is often referred to as an indicator of drought resistance in plants (Turner and Friese, 1998). The response to mycorrhiza was more pronounced in the drought-sensitive (CO) than -resistant (C8) maize cultivars, as the latter had selected drought tolerance (Edmeades et al., 1993). It offers evidence of support to the mycorrhizal responsiveness, which is governed by the inherent ability of the plant genotypes (Khalil et al., 1994; Hetrick et al., 1995). The literature clearly demonstrates that mycorrhiza supports plant growth under inhospitable weather conditions and such tolerance varies with intensities of drought stress and genetic potential of the genotypes.

\section{Biochemical changes in mycorrhizal-plant interactions under drought}

As a result of the greater acquisition of $\mathrm{NO}_{3}$ nitrogen at the root surface, AMF plants had higher $\mathrm{N}$ assimilating enzymes in roots (Subramanian and Charest, 1998). The first key enzyme in $\mathrm{N}$ assimilation is nitrate reductase which is a substrate inducible enzyme and its activities get increased with the concentration of nitrates in the rhizosphere. Indeed, such a greater influx of $\mathrm{N}$ modifies the GS-GOGAT pathway. The enhanced $\mathrm{N}$ assimilation enzymes activity was more pronounced in AMF plants indicating the tolerance to withstand drought conditions. On the other hand, Faure et al. (1998) showed a meager quantity of $\mathrm{NO}_{3}{ }^{-}$reduction in the fungal tissues in relation to the associated host plant roots (Faure et al., 1998). Cliquet and Stewart (1993) have shown enhanced nitrate reductase (NR) and glutamine synthetase (GS) activities in roots and shoots of maize plants colonized with G. fasciculatum (Cliquet and Stewart, 1993). The data suggest that $\mathrm{NO}_{3}{ }^{-}$ions sourced from the soil by AMF could be channeled further reduction and assimilation. The AMF colonized maize plants stimulated activities of $\mathrm{N}$ assimilating enzymes NR, GS and GOGAT under limited moisture conditions (Subramanian and Charest, 1998). Such improved $\mathrm{N}$ assimilation helped the host plant to withstand drought conditions and to recover rapidly when irrigation is restored.

In addition to the $\mathrm{N}$ assimilatory pathway, plants accumulate compatible solutes under limited water environments (Serraj and Sinclair, 2002). Compatible solutes are soluble organic compounds with low molecular weight and non-injurious (Hayat et al., 2010). while aiding in osmotic adjustment and quenching the reactive oxygen species (Yancey, 2001). Such osmolytes include proline, sugars, polyols, glycine betaine and proline betaine (Ashraf and Harris, 2004). The biosynthesis of osmolytes involves different biochemical pathways leading to a coordinated approach towards plant survival and growth under stress and limited nutrient availability conditions. The major osmolytes in plant system viz., proline, glycine betaine, pinitol, mannitol were synthesized using glutamic acid, choline, myoinositol and mannose-6-phosphate, respectively as precursors governed by specific enzymatic reactions. Ruiz-lozano et al., 2012, hypothesized that documenting the expression level of genes encoding crucial osmoprotectant generation enzymes viz., choline monooxygenase, mannose-6-phosphate reductase, inositol methyltransferase and pyrroline5carboxylate synthetase under AM inoculated and AM uninoculated plants would enable to establish the mechanism of AM mediated survival strategy by plants. (Ruiz-lozano et al., 2012)

Proline is one of the biochemical indicators of drought stress and its accumulation is associated with the degradation of proteins that resulted in osmotic adjustment mediated by mycorrhizal fungal colonization. Higher proline accumulation in Lactuca sativa (Azcón et al., 2008), Macadamia tetraphylla (Yooyongwech et al., 2013), and Oryza sativa (RuízSánchez., 2011), Zea mays (Subramanian and Charest, 1998) under drought stress have been reported. On the other hand, lower accumulation of proline in some of the AMF colonized plant species such as Erythrina variegata (Manoharan et al., 2010), Knautia arvensis (Doubková et al., 2013), Pistacia vera (Abbaspour et al., 2012), and Poncirus trifoliata (Zou ., 2013) were reported under limited water environments. The lower proline level in AMF plants is due to the inhibition of the glutamate synthetic pathway of proline (Zou et al., 2013). This reflects the reduced damage and greater water status. This suggests the proline changes by mycorrhization coincides with tolerance or avoidance of drought (Augé et al., 2003). The increase in proline concentrations in AMF plants assists osmotic adjustment as an organic osmolyte. The lower level in AMF plants is an indication of less injury caused by drought. It is an organic osmolyte aiding in maintaining cell turgor and osmotic balance. RuízLozano et al. (2012) elucidated the complexity of plant responses to AM symbiosis and indicated in one of the studies that the accumulation of higher proline content in the shoots of uninoculated plants (Ruiz-Lozano et al., 2012).

\section{Host-Plant Nitrogen Nutrition}

The AMF develops extensive hyphal networks in soil that facilitate scavenging of nutrients, primarily for $\mathrm{P}$ and $\mathrm{Zn}, \mathrm{N}$, and other nutrients (Walder et 
al., 2012; Watts-Williams and Cavagnaro, 2012). Mycorrhizas are well known to improve host plant $P$ nutrition as the inoculated or naturally colonized plants have access to the slowly diffusing phosphate ions. On the other hand, AMF aided $\mathrm{N}$ nutrition is less known for obvious reasons. This review highlights how the mycorrhizal symbiosis facilitates $\mathrm{N}$ nutrition which is equally important as that of $\mathrm{P}$, especially under limited water environments. The atmospheric $\mathrm{N}$ is sequestered into terrestrial ecosystems through atmospheric deposition and $\mathrm{N}$ fixation. The atmospheric $\mathrm{N}$ encompasses $\mathrm{N}_{2}(78 \%)$, $\mathrm{NO}, \mathrm{NO}_{3}$, and $\mathrm{NH}_{3}$ gas and they get fixed by soil and/ or plant symbiotic bacteria. After their fixation, the $\mathrm{N}$ fixed in organic matter gets mineralized as plant usable forms of N. Mycorrhizas excrete proteases, mineralize the organic matter and the released $\mathrm{N}$ gets entrapped in plant tissues indicating the direct path from organic nitrogen in the soil to the plant (Lehmann et al., 2014). This provides direct evidence that the host plant can access to $\mathrm{N}$ reserves that are generally inaccessible in the soil. Govindarajulu et al., 2005 reported the movement and transfer of $\mathrm{N}$ by tracking the dynamics and movement of amino acids introducing isotopically labelled substrates in AMF association with carrot (Daucus carota L.) under in vitro conditions. The findings suggest that the generation of glutamine using $\mathrm{NO}_{3}$ as a precursor and subsequent conversion into arginine occurs predominantly in extra-radical mycelium followed by mobilization to intraradical mycelium, which are established deep in the plant/host root system (Finlay, 2008). Further, the arginine is converted into urea in the presence of urease and ornithine, which are further downstream processed into $\mathrm{NH}_{4}^{+}$ ions that are amenable for translocation into host/ plant system. Transcriptome and gene expression profile analysis in two mycorrhizal sp. Gi. margarita and G. intraradices had vividly enumerated the putative genes and transporters involved in $\mathrm{N}$ uptake, transfer and assimilation in fungal and plant systems. Further, the magnitude of nitrogen uptake and transfer are complexly interlinked and are highly dependent on the amount of $\mathrm{N}$ and $\mathrm{P}$ available in the soil for exploitation (di Fossalunga and Novero, 2019).

\section{Improved $\mathbf{N}$ availability}

Drought tolerance of AMF plants is causally related to the improved host plant nutrition due to the fact that drought affects the diffusion of nutrients (Marschner et al., 1996). This is due to the transport of nutrients through the extra-radical or intraradical mycelium of AM fungi (Tisserant et al., 2012). The mycorrhizas assist the absorption of immobile soil nutrients, such as phosphorus $(P)$, zinc (Zn), Copper (Cu), manganese $(\mathrm{Mn})$, potassium (K), calcium (Ca), magnesium (Mg), and Fe (Sjoberg,
2005; Subramanian et al., 2006; Cornejo et al., 2008a, Cornejo et al., 2008b; Smith and Read, 2008; Subramanian et al., 2008; Cornejo et al., 2009; Evelin et al., 2012; Campanelli et al., 2013; Garg and Bhandari, 2016). AM also has the ability to improve nitrogen $(\mathrm{N})$ nutrition. The extra-radical mycelium transports both water and mineral nutrients across the root-soil interface (Smith and Smith, 2011).

In many ecosystems, nutrients get lost due to rain-induced leaching events. About $160 \mathrm{~kg}$ of $\mathrm{N}$ and $30 \mathrm{~kg}$ of $P$ per hectare is found to get leached out annually. Leaching losses cause environmental problems such as the eutrophication of aquatic ecosystems. The loss of nutrients varied widely depending on climate, land use and type of vegetation (Di and Cameron, 2002). The mycorrhizal symbiosis can circumvent the loss of nutrients while enhancing nutrient retention in soil (Corkidi et al., 2004).

The extensive hyphal networks assist efficient nutrient uptake and immobilization in plant and fungal biomass while minimizing the leaching of nutrients from the plant-mycorrhizal systems (Cavagnaro et al., 2015). The external mycelium entangles soil particles to develop stable aggregates that favor improvement in soil structure (Rillig and Mummey, 2006) and soil water retention. This assists in capturing nutrients in the soil system while leaving the least amounts of leachate; thereby, eutrophication of lakes and rivers are circumvented. Despite the fact that such evidence is rarely reported, the mechanisms involved are still to be explored(Cavagnaro et al., 2015). AM fungi influence not only plant growth and nutrient uptake but also ecosystem services such as nutrient retention.

The AMF facilitates the formation of stable aggregates that result in improved soil structure which reduces soil erosion while retaining the nutritional and water status (Barea et al., 2005; Curaqueo et al., 2010; Mardhiah et al., 2016). These fungal networks extend beyond the rhizosphere and constitute more than $50 \%$ of the fungal biomass(Olsson et al., 1995; Soka and Ritchie, 2015). Mycorrhizas assist in the formation of recalcitrant chitin and glomalin that contribute to the passive pool of carbon in the soil (Zhu and Miller, 2003). Glomalin, a glycoprotein and water-insoluble proteins favour stable soil aggregates formation that is often altered by tillage systems and soil management (Miller and Jastrow, 2000; Cornejo et al., 2008a; Cornejo et al., 2008b; Cornejo et al., 2009; Curaqueo et al., 2011; Cornejo et al., 2017). The improved soil structure in combination with the presence of glomalin and chitin may conserve the soil organic $\mathrm{N}$ and improve the available $\mathrm{N}$ on 
mineralization. Fellbaum et al., 2012 elucidated the mechanisms involved in biogeocycling of nutrients by differentially altering the $C$ supply to the host and subsequent changes in uptake and transfer of $\mathrm{N}$ in AMF They found that the $\mathrm{C}$ supply from the host plant invokes biochemical changes that mediate uptake and transport of $\mathrm{N}$ in the symbiosis a phenomenon that is governed by respective changes in fungal gene expression especially in adequate $\mathrm{C}$ availability. The addition of sucrose to the AMF inoculated plants led to increased transcript levels of genes involved in N assimilation (GluS and GS2) and Arg biosynthesis (AL, ASS, and CPS), but decreased transcript levels of a high-affinity nitrate transporter (NT) and fungal urease (URE) in the extra-radical mycelium. This study demonstrated that cooperation in the AM symbiosis is stabilized by a reciprocal reward mechanism ie., AMF fungi rewards its host with an increase in $\mathrm{N}$ transport in response to higher $\mathrm{C}$ rewards. Although $\mathrm{AM}$ fungi will always need a host plant to complete their life cycle, they gain an advantage in symbiosis by adjusting their nutrient transfer, both $\mathrm{N}$ and $\mathrm{P}$, in response to the $C$ supply from the host (Fellbaum et al., 2012). Thus mycorrhiza is a key factor in biogeocycling of $\mathrm{N}$ in soils. This process helps the host plants to survive under extreme drought conditions in arid and semi-arid regions.

In contrast, Reynolds et al., (2005) had suggested AMF does not promote plant $\mathrm{N}$ acquisition at low $\mathrm{N}$ supply and that AMF can act as a parasitic carbon drain when phosphorus availability is relatively high. The study had explored whether AMF can enhance the ability of plants to thrive on organic forms of $\mathrm{N}$ compared to mineral forms at low $\mathrm{N}$ levels. Photosynthate production is also highly limited by $\mathrm{N}$ availability since plants require substantial amounts of $\mathrm{N}$, where almost 50 percent of $\mathrm{N}$ in a leaf is allocated towards photosynthesis. In this context, for the fungal symbiosis to be of mutual benefit to plant under $\mathrm{N}$-limiting conditions, AMF must mediate to increase the access of plants to $\mathrm{N}$ to the extent of attaining sufficiency not only to meet the plant demand but also the requirements of fungal symbiosis. Johnson et al., 1997 and Reynolds et al., (2005) indicated that the trade-off between the host plant and AMF is considered negative for high $\mathrm{N}$ demanding crops under $\mathrm{N}$ starved conditions (Reynolds et al., 2005). Fitter earlier reported such observations, 1988 that red clover (Trifolium pratense L.) plants had retained higher conductance and water uptake in combination with high $\mathrm{P}$ concentrations irrespective of irrigated or drought-stressed conditions and thus, there was no conclusive evidence of increased uptake of water among AMF inoculated and uninoculated plants. Further, Auge, 2001 reported that plant water relations and the performance of host plants under phosphorus-rich and deficient conditions were not coherent. No significant and consistent impact was observed in plant water uptake and transport, whereas $\mathrm{P}$ acquisition and growth did positively correlate with the level of mycorrhizal colonization. Similar to plant water relation, the influence of AMF on stomatal movement and tissue hydration is mostly subtle and transient. Mechanisms and its associated changes involved in mycorrhizae-aided drought tolerance in host plants are summarised in Fig.1. Despite the fact that the AMF aided host plant water relation has nutritionally related to either $\mathrm{P}$ or $\mathrm{N}$ or combination of both, the mechanism involved is still unclear and warrants further research.

\section{Responses of mycorrhizal plants}

Mycorrhizal fungal colonization improved the growth attributes of a wide array of plants and it varied with the genotypes and intensities of drought stress (Subramanian and Charest, 1997; Subramanian et al., 2006; Janos, 2007). Plant growth responses to AM inoculation varied widely with AMF species and agro-climatic conditions (Augé et al., 2003; Klironomos, 2003). For instance, Bryla and Koide (1998) reported that two cultivars of tomato (LA1709 and large cherry) had a differential response to drought stress at the early stage of growth in the absence or presence of mycorrhizal symbiosis. (Bryla and Koide, 1998). The genotype LA1709 exhibited higher responses in dry mass, root length, and $\mathrm{P}$ content than the large cherry genotype. Similarly, drought-sensitive maize genotype $\left(C_{0}\right)$ exhibited a higher rate of AMF colonization in contrast to drought-tolerant (C8) genotype when the drought coincided with vegetative(Subramanian and Charest, 1995) and reproductive stage (Subramanian et al., 1997). Interestingly, the AMF colonized maize plants had a shorter anthesis - silking interval which is of utmost essential to improve the productivity of maize under drought conditions (Subramanian and Charest, 1997).

Several studies have unequivocally demonstrated that AMF symbiosis improved the productivity of crops such as sorghum (Raju et al., 1990), maize (Sylvia et al., 1993; Lu et al., 1994), potato (McArthur and Knowles, 1993), soybean (Bethlenfalvay et al., 1988), and tomato (Subramanian et al., 2006). In many cases, responses to mycorrhizal symbiosis were primarily attributed to the improved macro and micronutrient status of soil that are immobile or slowly diffusing in the rhizosphere (Nelsen, 1987; Kothari et al., 1990; Frey and Schüepp, 1993; Subramanian et al., 2008). The hyphal contribution towards host plant nutrition has been well established for $P$ due to access to the $P$, which is rarely transported through slow diffusion processes (Vézina et al., 1989). The AMF response increased with decreasing gradient of soil fertility (Jeffries 
and Rhodes, 1987) and with increasing intensity of drought stress (Sylvia et al., 1993; Subramanian et al., 2006). These data demonstrate that the AM fungus plays a key role in nutrient acquisition that indirectly improves the drought resistance under constraints of moisture or nutrient status (Morgan et al., 1994).

\section{CONCLUSION}

The major part of the benefits of mycorrhizas on drought tolerance was focused on phosphorus nutrition as it is a highly immobile nutrient and its movement is further impeded by drought. On the other hand, the importance of AMF aided host plant $\mathrm{N}$ nutrition is frequently debated. Many have suggested that the potential $\mathrm{N}$ uptake and transport rates of roots are much higher than those by hyphae in terms of their relative abundance and distribution. But the data presented in the reported literature are quite variable and inconclusive. Extensive studies and $\mathrm{N}$ dynamics between $\mathrm{AM}$ fungi and host plants may assist in quantifying $\mathrm{N}$ uptake processes in individual plants and such transfers may influence the global $\mathrm{N}$ cycles. Although $\mathrm{N}$ transfer by AM fungi to host plants is reported, it is still unclear whether various forms of $\mathrm{N}$ get transferred to the host plant roots.

Drought is the single most crucial factor determining agricultural production and sustainability of natural ecosystems. However, drought exerts selection pressure for the indigenous AMF to cope with the limiting conditions and support the growth and development of plants to survive under arid and semi-arid regions. The impact of AMF on plant responses to drought stress depends on the ability of the AMF to withstand inhospitable weather conditions. In order to gain insights into the mechanisms associated with mycorrhizaaided drought tolerance concerning $\mathrm{N}$ nutrition and assimilation, steps have to be undertaken to precisely determine the nutrient transfer from the mycorrhizas to the host plant using advanced tools and techniques. The literature review has clearly shown that there is an urgent need to explore plantmycorrhizal symbiosis from a different perspective to gain insights into the mechanisms associated with $\mathrm{N}$ nutritionally aided drought tolerance. Plant biochemical and physiological mechanisms associated with AMF symbiosis are to be studied extensively. This will lead to the technological development of AMF-based biofertilizers, which enable the establishment of highly effective combinations of plants and fungi.

\section{Consent for publication}

All the authors agreed to publish the content.

\section{Competing interests}

There were no conflict of interest in the publication of this content.

\section{REFERENCES}

Abbaspour, H., Saeidi-Sar, S., Afshari, H., and AbdelWahhab, M. 2012. Tolerance of mycorrhiza infected pistachio (Pistacia vera L.) seedling to drought stress under glasshouse conditions. J. of plant physiol., 169(7): 704-709.

Aggarwal, A., Kadian, N., Karishma, K., Neetu, N., Tanwar, A., and Gupta, K. 2012. Arbuscular mycorrhizal symbiosis and alleviation of salinity stress. J. Appl. Nat. Sci. 4(1): 144-155.

Allen, M.F. 1982. Influence of vesicular-arbuscular mycorrhizae on water movement through Bouteloua gracilis (HBK) Lag ex Steud. New Phytol. 91(2): 191-196.

Ashraf, M., and Harris, P. 2004. Potential biochemical indicators of salinity tolerance in plants. Plant Sci. J. 166(1): 3-16.

Augé, R.M. 2001. Water relations, drought and vesiculararbuscular mycorrhizal symbiosis. Mycorrhiza 11(1): 3-42.

Augé, R.M., Moore, J.L., Cho, K., Stutz, J.C., Sylvia, D.M., Al-Agely, A.K., et al. 2003. Relating foliar dehydration tolerance of mycorrhizal Phaseolus vulgaris to soil and root colonization by hyphae. J. Plant Physiol. 160(10): 1147-1156.

Azcón-Aguilar, C., and Barea, J. 1997. Arbuscular mycorrhizas and biological control of soil-borne plant pathogens-an overview of the mechanisms involved. Mycorrhiza 6(6): 457-464.

Azcón, R., Rodríguez, R., Amora-Lazcano, E., and Ambrosano, E. 2008. Uptake and metabolism of nitrate in mycorrhizal plants as affected by water availability and $\mathrm{N}$ concentration in soil. Eur. J.Soil Sci. 59(2): 131-138.

Bago, B., Azcón-Aguilar, C., and Piché, Y. 1998. Architecture and developmental dynamics of the external mycelium of the arbuscular mycorrhizal fungus Glomus intraradices grown under monoxenic conditions. Mycologia 90(1): 52-62.

Bago, B., Pfeffer, P.E., Zipfel, W., Lammers, P., and Shachar-Hill, Y. 2002. Tracking metabolism and imaging transport in arbuscular mycorrhizal fungi. Metabolism and transport in AM fungi. Plant and Soil 244(1): 189-197.

Barea, J.-M., Pozo, M.J., Azcon, R., and Azcon-Aguilar, C. 2005. Microbial co-operation in the rhizosphere. J. Exp. Biol. 56(417): 1761-1778.

Barea, J., El-Atrach, F., and Azcon, R. 1989. Mycorrhiza and phosphate interactions as affecting plant development, $\mathrm{N}_{2}$-fixation, $\mathrm{N}$-transfer and $\mathrm{N}$-uptake from soil in legume-grass mixtures by using a $15 \mathrm{~N}$ dilution technique. Soil Biol. Biochem. 21(4): 581-589.

Bárzana, G., Aroca, R., and Ruiz-Lozano, J.M. 2015. Localized and non-localized effects of arbuscular mycorrhizal symbiosis on accumulation of 
osmolytes and aquaporins and on antioxidant systems in maize plants subjected to total or partial root drying. Plant Cell Environ. 38(8):1613-1627.

Bethlenfalvay, G., Mihara, K., Schreiner, R., and McDaniel, H. 1996. Mycorrhizae, biocides, and biocontrol. Herbicide-mycorrhiza interactions in soybean and cocklebur treated with bentazon. Appl. Soil Ecol. 3(3): 197-204.

Bethlenfalvay, G.J., Brown, M.S., Ames, R.N., and Thomas, R.S. 1988. Effects of drought on host and endophyte development in mycorrhizal soybeans in relation to water use and phosphate uptake. Physiol. Plant. 72(3): 565-571.

Blackwell, J. 1988. Physical methods for the determination of chitin structure and conformation, in Methods in enzymol. 12:435-442.

Bowen, G., and Smith, S. 1981. Effects of mycorrhizas on nitrogen uptake by plants. Ecol. Bull. (Stockholm) 33:237-247.

Bryla, D.R., and Koide, R.T. 1998. Mycorrhizal response of two tomato genotypes relates to their ability to acquire and utilize phosphorus. Ann. Bot. 82(6): 849-857.

Calvo-Polanco, M., Sánchez-Romera, B., Aroca, R., Asins, M.J., Declerck, S., Dodd, I.C., et al. 2016. Exploring the use of recombinant inbred lines in combination with beneficial microbial inoculants (AM fungus and PGPR) to improve drought stress tolerance in tomato. Environ. Exp. Bot. 131: 47-57.

Campanelli, A., Ruta, C., De Mastro, G., and MoroneFortunato, I. 2013. The role of arbuscular mycorrhizal fungi in alleviating salt stress in Medicago sativa L. var. icon. Symbiosis 59(2): 65-76.

Cattivelli, L., Rizza, F., Badeck, F.-W., Mazzucotelli, E., Mastrangelo, A.M., Francia, E., et al. 2008. Drought tolerance improvement in crop plants: an integrated view from breeding to genomics. Field Crops Res. 105(1): 1-14.

Cavagnaro, T.R., Bender, S.F., Asghari, H.R., and van der Heijden, M.G. 2015. The role of arbuscular mycorrhizas in reducing soil nutrient loss. Trends in Plant Sci. 20(5): 283-290.

Chalot, M., Brun, A., Finlay, R.D., and Söderström, B. 1994. Metabolism of [14C] glutamate and [14C] glutamine by the ectomycorrhizal fungus Paxillus involutus. Microbiol. 140(7): 1641-1649.

Chapin, F.S., Bloom, A.J., Field, C.B., and Waring, R.H. 1987. Plant responses to multiple environmental factors. Bioscience 37(1): 49-57.

Clark, R., and Zeto, S. 2000. Mineral acquisition by arbuscular mycorrhizal plants. J. Plant Nutr. 23(7): 867-902.

Cliquet, J.-B., and Stewart, G.R. 1993. Ammonia assimilation in Zea mays $\mathrm{L}$. infected with a vesicular-arbuscular mycorrhizal fungus Glomus fasciculatum. Plant Physiol. 101(3): 865-871.

Corkidi, L., Allen, E.B., Merhaut, D., Allen, M.F., Downer, J., Bohn, J., et al. 2004. Assessing the infectivity of commercial mycorrhizal inoculants in plant nursery conditions. J. of Environ. Hortic. 22(3): 149-154.
Cornejo, P., Meier, S., Borie, G., Rillig, M.C., and Borie, F. 2008a. Glomalin-related soil protein in a Mediterranean ecosystem affected by a copper smelter and its contribution to $\mathrm{Cu}$ and Zn sequestration. Sci. Total Environ. 406(1-2): 154-160.

Cornejo, P., Meier, S., García, S., Ferrol, N., Durán, P., Borie, F., et al. 2017. Contribution of inoculation with arbuscular mycorrhizal fungi to the bioremediation of a copper contaminated soil using Oenothera picensis. J. of Soil Sci. Plant Nutr. 17(1): 14-21.

Cornejo, P., Rubio, R., and Borie, F. 2009. Mycorrhizal propagule persistence in a succession of cereals in a disturbed and undisturbed andisol fertilized with two nitrogen sources. Chil. J. Agric. Res. 69(3): 426-434.

Cornejo, P., Rubio, R., Castillo, C., Azcón, R., and Borie, F. 2008b. Mycorrhizal effectiveness on wheat nutrient acquisition in an acidic soil from southern Chile as affected by nitrogen sources. J. Plant Nutr. 31(9): 1555-1569.

Cruz, C., Egsgaard, H., Trujillo, C., Ambus, P., Requena, N., Martins-Loução, M. A., \& Jakobsen, I. 2007. Enzymatic evidence for the key role of arginine in nitrogen translocation by arbuscular mycorrhizal fungi. Plant physiol. 144(2): 782-792.

Curaqueo, G., Acevedo, E., Cornejo, P., Seguel, A., Rubio, R., and Borie, F. 2010. Tillage effect on soil organic matter, mycorrhizal hyphae and aggregates in a mediterranean agroecosystem. Revista de la ciencia del suelo y nutrición vegetal 10(1): 12-21.

Curaqueo, G., Barea, J.M., Acevedo, E., Rubio, R., Cornejo, P., and Borie, F. 2011. Effects of different tillage system on arbuscular mycorrhizal fungal propagules and physical properties in a Mediterranean agroecosystem in central Chile. Soil and Tillage Res. 113(1): 11-18.

di Fossalunga, A. S. and Novero, M. 2019. To trade in the field: the molecular determinants of arbuscular mycorrhiza nutrient exchange. Chem. Biol. Technol. 6(1): 12

Di, H., and Cameron, K. 2002. Nitrate leaching in temperate agroecosystems: sources, factors and mitigating strategies. Nutr. Cycl. Agroecosys. 64(3): 237-256.

Doubková, P., Kohout, P., and Sudová, R. 2013. Soil nutritional status, not inoculum identity, primarily determines the effect of arbuscular mycorrhizal fungi on the growth of Knautia arvensis plants. Mycorrhiza 23(7): 561-572.

Drüge, U., and Schonbeck, F. 1993. Effect of vesiculararbuscular mycorrhizal infection on transpiration, photosynthesis and growth of flax (Linum usitatissimum L.) in relation to cytokinin levels. J. of Plant Physiol. 141(1): 40-48.

Edmeades, G., Bolaños, J., Hernandez, M., and Bello, S. 1993. Causes for silk delay in a lowland tropical maize population. Crop Sci. 33(5): 1029-1035.

Esfahani, M., Abbasi, H. A., Rabiei, B., \& Kavousi, M. 2008. Improvement of nitrogen management in rice paddy fields using chlorophyll meter (SPAD). Paddy and Water Environ. 6(2): 181-188. 
Estrada, B., Aroca, R., Maathuis, F.J., Barea, J.M., and Ruiz-Lozano, J.M. 2013. Arbuscular mycorrhizal fungi native from a $\mathrm{M}$ editerranean saline area enhance maize tolerance to salinity through improved ion homeostasis. Plant cell environ. 36(10): 1771-1782.

Evelin, H., Giri, B., and Kapoor, R. 2012. Contribution of Glomus intraradices inoculation to nutrient acquisition and mitigation of ionic imbalance in $\mathrm{NaCl}$-stressed Trigonella foenum-graecum. Mycorrhiza 22(3): 203-217.

Faber, B.A., Zasoski, R.J., Munns, D.N., and Shackel, K. 1991. A method for measuring hyphal nutrient and water uptake in mycorrhizal plants. Can. J. Bot. 69(1): 87-94.

Faure, S., Cliquet, J.B., Thephany, G., and Boucaud, J. 1998. Nitrogen assimilation in Lolium perenne colonized by the arbuscular mycorrhizal fungus Glomus fasciculatum. New Phytol. 138(3): 411417.

Fellbaum, C.R., Gachomo, E.W., Beesetty, Y., Choudhari, S., Strahan, G.D., Pfeffer, P.E., et al. 2012. Carbon availability triggers fungal nitrogen uptake and transport in arbuscular mycorrhizal symbiosis. Proc. Natl. Acad.Sci. 109(7): 2666-2671.

Finlay, R. D. 2008. Ecological aspects of mycorrhizal symbiosis: with special emphasis on the functional diversity of interactions involving the extra-radical mycelium. J. Exp. Bot. 59(5): 1115-1126.

Fischlin, A., Midgley, G., Price, J., Leemans, R., Gopal, B., Turley, C., et al. 2007. Ecosystems their properties goods and services. Climate Change 2007: Impacts Adaptation and Vulnerability. Contribution of Working Group II to the Fourth Assessment Report of the Intergovernmental Panel on Climate Change ML Parry OF Canziani JP Palutikof PJ van der Linden and CE Hanson Eds. Cambridge University Press Cambridge. Assessment Report of the Intergovernmental Panel on Climate Change 4: 211-272.

Fitter, A. 1985. Functioning of vesicular-arbuscular mycorrhizas under field conditions. New Phytol. 99(2): 257-265.

Fitter, A. H. 1988. Water relations of red clover Trifolium pratense $\mathrm{L}$. as affected by VA mycorrhizal infection and phosphorus supply before and during drought. J. Exp. Bot. 39(5): 595-603.

Forgy, D. 2012. Arbuscular mycorrhizal fungi can benefit heavy metal tolerance and phytoremediation. J. Nat. Resour. Life Sci. Educ. 41(1): 23-26.

Fochi, V., Chitarra, W., Kohler, A., Voyron, S., Singan, V. R., Lindquist, E. A., \& Balestrini, R. 2017. Fungal and plant gene expression in the Tulasnella calosporaSerapias vomeracea symbiosis provides clues about nitrogen pathways in orchid mycorrhizas. New Phytol. 213(1): 365-379.

Frey, B., and Schüepp, H. 1993. Acquisition of nitrogen by external hyphae of arbuscular mycorrhizal fung associated with Zea mays L. New Phytol. 124(2): 221-230.
Fukasawa, Y., Osono, T., and Takeda, H. 2009. Effects of attack of saprobic fungi on twig litter decomposition by endophytic fungi. Ecol. Res. 24(5): 1067-1073.

Garg, N., and Bhandari, P. 2016. Interactive effects of silicon and arbuscular mycorrhiza in modulating ascorbate-glutathione cycle and antioxidant scavenging capacity in differentially salt-tolerant Cicer arietinum $\mathrm{L}$. genotypes subjected to long-term salinity. Protoplasma 253(5): 1325-1345.

George, E., Häussler, K.-U., Vetterlein, D., Gorgus, E., and Marschner, H. 1992. Water and nutrient translocation by hyphae of Glomus mosseae. Can. J. Bot. 70(11): 2130-2137.

Govindarajulu, M., Pfeffer, P. E., Jin, H., Abubaker, J., Douds, D. D., Allen, J. W., \& Shachar-Hill, Y. 2005. Nitrogen transfer in the arbuscular mycorrhizal symbiosis. Nature 435(7043): 819.

Gupta, M., and Janardhanan, K. 1991. Mycorrhizal association of Glomus aggregatum with palmarosa enhances growth and biomass. Plant and soil 131(2): 261-263.

Guether, M., Neuhäuser, B., Balestrini, R., Dynowski, M., Ludewig, U., \& Bonfante, P. 2009. A mycorrhizalspecific ammonium transporter from Lotus japonicus acquires nitrogen released by arbuscular mycorrhizal fungi. Plant Physiol. 150(1): 73-83.

Hajiboland, R. 2013. "Role of arbuscular mycorrhiza in amelioration of salinity," in Salt stress in plants. Springer, 301-354.

Hammer, E.C., Nasr, H., Pallon, J., Olsson, P.A., and Wallander, H. 2011. Elemental composition of arbuscular mycorrhizal fungi at high salinity. Mycorrhiza 21(2):117-129.

Hardie, K. 1985. The effect of removal of extra-radical hyphae on water uptake by vesicular-arbuscular mycorrhizal plants. New Phytol. 101(4): 677-684.

Harley, J. 1989. The significance of mycorrhiza. Mycol. Res. 92(2): 129-139.

Hawkins, H.J., and George, E. 1999. Effect of plant nitrogen status on the contribution of arbuscular mycorrhizal hyphae to plant nitrogen uptake. Physiol. Plant. 105(4): 694-700.

Hayat, R., Ali, S., Amara, U., Khalid, R., and Ahmed, I. 2010. Soil beneficial bacteria and their role in plant growth promotion: a review. Ann. microbiol. 60(4): 579-598.

Haystead, A., Malajczuk, N., and Grove, T. 1988. Underground transfer of nitrogen between pasture plants infected with vesicular-arbuscular mycorrhizal fungi. New Phytol. 108(4): 417-423.

Heap, A.J., and Newman, E. 1980. The influence of vesicular-arbuscular mycorrhizas on phosphorus transfer between plants. New Phytol. 85(2): 173179

Hetrick, B., Wilson, G., Gill, B., and Cox, T. 1995. Chromosome location of mycorrhizal responsive genes in wheat. Can. J. Bot. 73(6): 891-897.

Hidri, R., Barea, J., Mahmoud, O.M.-B., Abdelly, C., and Azcón, R. 2016. Impact of microbial inoculation on biomass accumulation by Sulla 
carnosa provenances, and in regulating nutrition, physiological and antioxidant activities of this species under non-saline and saline conditions. $J$. Plant physiol. 201: 28-41.

Ho, I., and Trappe, J. 1975. Nitrate reducing capacity of two vesicular arbuscular mycorrhizal fungi. Mycologia 67(4): 886-888.

Hodge, A., and Fitter, A. H. 2010. Substantial nitrogen acquisition by arbuscular mycorrhizal fungi from organic material has implications for $\mathrm{N}$ cycling. Proc. Nat. Acad. Sci. 107(31): 13754-13759.

Hodge, A., and Storer, K. 2015. Arbuscular mycorrhiza and nitrogen: implications for individual plants through to ecosystems. Plant and soil 386(1-2): 1-19.

Ibijbijen, J., Urquiaga, S., Ismaili, M., Alves, B., and Boddey, R. 1996. Effect of arbuscular mycorrhizal fungi on growth, mineral nutrition and nitrogen fixation of three varieties of common beans (Phaseolus vulgaris). New Phytol. 134(2): 353360.

Janos, D.P. 2007. Plant responsiveness to mycorrhizas differs from dependence upon mycorrhizas. Mycorrhiza 17(2): 75-91.

Jeffries, P., and Rhodes, L.H. 1987. Use of mycorrhizae in agriculture. Critical Reviews in Biotechnology 5(4): 319-357.

Jin, H., Pfeffer, P. E., Douds, D. D., Piotrowski, E., Lammers, P. J., \& Shachar-Hill, Y. 2005. The uptake, metabolism, transport and transfer of nitrogen in an arbuscular mycorrhizal symbiosis. New Phytol. 168(3): 687-69.

Johansen, A., Jakobsen, I., and Jensen, E. 1992. Hyphal transport of ${ }^{15} \mathrm{~N}$-labelled nitrogen by a vesiculararbuscular mycorrhizal fungus and its effect on depletion of inorganic soil N. New Phytol. 122(2): 281-288.

Johnson, N. C., Graham, J. H., \& Smith, F. A. 1997. Functioning of mycorrhizal associations along the mutualism-parasitism continuum. The New Phytol. 135(4): 575-585.

Jung, S.C., Martinez-Medina, A., Lopez-Raez, J.A., and Pozo, M.J. 2012. Mycorrhiza-induced resistance and priming of plant defenses. J. Chem. Ecol. 38(6): 651-664.

Kaldorf, M., and Ludwig-Müller, J. 2000. AM fungi might affect the root morphology of maize by increasing indole-3-butyric acid biosynthesis. Physiol. Plant. 109(1): 58-67.

Kaushal, M., and Wani, S.P. 2016. Rhizobacterial-plant interactions: strategies ensuring plant growth promotion under drought and salinity stress. Agric. Ecosyst. Environ. 231: 68-78.

Khalil, S., Loynachan, T.E., and Tabatabai, M.A. 1994. Mycorrhizal dependency and nutrient uptake by improved and unimproved corn and soybean cultivars. J. Agron. 86(6): 949-958.

Khoyerdi, F.F., Shamshiri, M.H., and Estaji, A. 2016. Changes in some physiological and osmotic parameters of several pistachio genotypes under drought stress. Sci. Hortic. 198: 44-51.
Kiers, E.T., Duhamel, M., Beesetty, Y., Mensah, J.A., Franken, O., Verbruggen, E., et al. 2011. Reciprocal rewards stabilize cooperation in the mycorrhizal symbiosis. Science 333(6044): 880-882.

Klironomos, J.N. 2003. Variation in plant response to native and exotic arbuscular mycorrhizal fungi. Ecology 84(9): 2292-2301.

Knapp, A., Briggs, J., and Koelliker, J. 2001. Frequency and extent of water limitation to primary production in a mesic temperate grassland. Ecosystems 4(1): 19-28.

Koide, R.T. 1993. Physiology of the mycorrhizal plant. Adv Plant Pathol 9: 33-54.

Kolenc, Z., Vodnik, D., Mandelc, S., Javornik, B., Kastelec, D., and erenak, A. 2016. Hop (Humulus Iupulus L.) response mechanisms in drought stress: Proteomic analysis with physiology. Plant physiol. biochem. 105: 67-78.

Kothari, S., Marschner, H., and George, E. 1990. Effect of VA mycorrhizal fungi and rhizosphere microorganisms on root and shoot morphology, growth and water relations in maize. New Phytol. 116(2): 303-311.

Kramer, P.J., and Boyer, J.S. 1995. Water relations of plants and soils. Academic press.

Kumar, P., Lucini, L., Rouphael, Y., Cardarelli, M., Kalunke, R. M., \& Colla, G. 2015. Insight into the role of grafting and arbuscular mycorrhiza on cadmium stress tolerance in tomato. Front. Plant. Sci. 6: 477.

Lambers, H., Chapin III, F.S., and Pons, T.L. 2008. Plant physiological ecology. Springer Science \& Business Media.

Lehmann, A., Veresoglou, S.D., Leifheit, E.F., and Rillig, M.C. 2014. Arbuscular mycorrhizal influence on zinc nutrition in crop plants-a meta-analysis. Soil Biol. and Biochem. 69: 123-131.

Lilleskov, E. A., Kuyper, T. W., Bidartondo, M. I., \& Hobbie, E. A. 2018. Atmospheric nitrogen deposition impacts on the structure and function of forest mycorrhizal communities: a review. Environ. Pollut. 246:148-162

Lu, S., Braunberger, P., and Miller, M. 1994. Response of vesicular-arbuscular mycorrhizas of maize to various rates of $\mathrm{P}$ addition to different rooting zones. Plant and Soil 158(1) 119-128.

Manoharan, P., Shanmugaiah, V., Balasubramanian, N., Gomathinayagam, S., Sharma, M.P., and Muthuchelian, K. 2010. Influence of AM fungi on the growth and physiological status of Erythrina variegata Linn. grown under different water stress conditions. Eur. J. Soil. Biol. 46(2):151-156.

Mardhiah, U., Caruso, T., Gurnell, A., and Rillig, M.C. 2016. Arbuscular mycorrhizal fungal hyphae reduce soil erosion by surface water flow in a greenhouse experiment. Appl. Soil Ecol. 99: 137-140.

Marschner, H., Kirkby, E., and Cakmak, I. 1996. Effect of mineral nutritional status on shoot-root partitioning of photoassimilates and cycling of mineral nutrients. J. Exp. Bot. 47: 1255-1263. 
Martins, M.A., and Cruz, A.F. 1998. The role of the external mycelial network of arbuscular mycorrhizal fungi: III. A study of nitrogen transfer between plants interconnected by a common mycelium. Rev. Argent. Microbiol. 29(4): 289-294.

Marulanda, A., Azcon, R., and Ruiz-Lozano, J.M. 2003. Contribution of six arbuscular mycorrhizal fungal isolates to water uptake by Lactuca sativa plants under drought stress. Physiol. Plant. 119(4): 526-533.

Maya, M.A., and Matsubara, Y.-i. 2013. Influence of arbuscular mycorrhiza on the growth and antioxidative activity in cyclamen under heat stress. Mycorrhiza 23(5): 381-390.

MacLean, A. M., Bravo, A., \& Harrison, M. J. 2017. Plant signaling and metabolic pathways enabling arbuscular mycorrhizal symbiosis. The Plant Cell, 29(10): 2319-2335.

McArthur, D.A., and Knowles, N.R. 1993. Influence of species of vesicular-arbuscular mycorrhizal fungi and phosphorus nutrition on growth, development, and mineral nutrition of potato (Solanum tuberosum L.). Plant Physiol. 102(3): 771-782.

Miller, R., and Jastrow, J. 2000. "Mycorrhizal fungi influence soil structure," in Arbuscular mycorrhizas: physiology and function. 3:18.

Miransari, M. 2013. "Arbuscular mycorrhizal fungi and uptake of nutrients," in Symbiotic endophytes. Springer, 253-270.

Morgan, J., Knight, W., Dudley, L., and Hunt, H. 1994. "Enhanced root system C-sink activity, water relations and aspects of nutrient acquisition in mycotrophic Bouteloua gracilis subjected to $\mathrm{CO}$ 2 enrichment," in Belowground Responses to Rising Atmospheric CO2: Implications for Plants, Soil Biota, and Ecosystem Processes. Springer, 139-146.

Nadeem, S.M., Ahmad, M., Zahir, Z.A., Javaid, A., and Ashraf, M. 2014. The role of mycorrhizae and plant growth promoting rhizobacteria (PGPR) in improving crop productivity under stressful environments. Biotechnol. Adv. 32(2): 429-448.

Nelsen, C.E. 1987. The water relations of vesicular arbuscular mycorrhizal systems.

Netto, A. T., Campostrini, E., de Oliveira, J. G., \& Bressan-Smith, R. E. 2005. Photosynthetic pigments, nitrogen, chlorophyll a fluorescence and SPAD-502 readings in coffee leaves. Sci. Hortic. 104(2): 199-209.

Newman, E., and Ritz, K. 1986. Evidence on the pathways of phosphorus transfer between vesicular-arbuscular mycorrhizal plants. New phytol. 104(1): 77-87.

Olsson, P.A., Bååth, E., Jakobsen, I., and Söderström, B. 1995. The use of phospholipid and neutral lipid fatty acids to estimate biomass of arbuscular mycorrhizal fungi in soil. Mycol. Res. 99(5): 623 629.

Ortiz, N., Armada, E., Duque, E., Roldán, A., \& Azcón, R. 2015. Contribution of arbuscular mycorrhizal fungi and/or bacteria to enhancing plant drought tolerance under natural soil conditions: effectiveness of autochthonous or allochthonous strains. J. Plant Physiol. 174: 87-96.

Parniske, M. 2000. Intracellular accommodation of microbes by plants: a common developmental program for symbiosis and disease?. Curr. Opin. Plant Biol. 3(4): 320-328.

Peterson, R.L., Massicotte, H.B., and Melville, L.H. 2004. Mycorrhizas: anatomy and cell biology. NRC Research Press.

Querejeta, J., Allen, M., Caravaca, F., and Roldán, A. 2006. Differential modulation of host plant $13 \mathrm{C}$ and 180 by native and non native arbuscular mycorrhizal fungi in a semi arid environment. New Phytol. 169(2): 379-387.

Raju, P., Clark, R., Ellis, J., and Maranville, J. 1990. Effects of species of VA-mycorrhizal fungi on growth and mineral uptake of sorghum at different temperatures. Plant and Soil 121(2): 165-170.

Rapti-Caputo, D. 2010. Influence of climatic changes and human activities on the salinization process of coastal aquifer systems. Ital. J. Agron. 5: 67-80.

Read, D., and Boyd, R. 1986. Water relations of mycorrhizal fungi and their host plants. Water, fungi and plants. Cambridge University Press, Cambridge, 287-303.

Reynolds, H. L., Hartley, A. E., Vogelsang, K. M., Bever, J. D., \& Schultz, P. A. 2005. Arbuscular mycorrhizal fungi do not enhance nitrogen acquisition and growth of old-field perennials under low nitrogen supply in glasshouse culture. New Phytol. 167(3): 869-880.

Rillig, M.C., and Mummey, D.L. 2006. Mycorrhizas and soil structure. New Phytologist 171(1): 41-53.

Ruiz-Lozano, J.M., Porcel, R., Azcón, C., and Aroca, R. 2012. Regulation by arbuscular mycorrhizae of the integrated physiological response to salinity in plants: new challenges in physiological and molecular studies. J. Exp. Bot. 63(11): 40334044.

Ruiz-Lozano, J., and Azcón, R. 1995. Hyphal contribution to water uptake in mycorrhizal plants as affected by the fungal species and water status. Physiol. Plant. 95(3): 472-478.

Ruíz-Sánchez, M., Armada, E., Muñoz, Y., de Salamone, I. E. G., Aroca, R., Ruíz-Lozano, J. M., \& Azcón, R. 2011. Azospirillum and arbuscular mycorrhizal colonization enhance rice growth and physiological traits under well-watered and drought conditions. J. Plant physiol. 168(10): 1031-1037.

Sanchez-Bel, P., Troncho, P., Gamir, J., Pozo, M. J., Camañes, G., Cerezo, M., \& Flors, V. 2016. The nitrogen availability interferes with mycorrhizainduced resistance against Botrytis cinerea in tomato. Front. Microbiol. 7: 1598.

Sanchez-Diaz, M., and Honrubia, M. 1994. "Water relations and alleviation of drought stress in mycorrhizal plants," in Impact of arbuscular mycorrhizas on sustainable agriculture and natural ecosystems. Springer, 167-178. 
Sasan, R.K., and Bidochka, M.J. 2012. The insectpathogenic fungus Metarhizium robertsii (Clavicipitaceae) is also an endophyte that stimulates plant root development. Am. J. Bot. 99(1): 101-107.

Schreiner, R.P. 2003. Mycorrhizal colonization of grapevine rootstocks under field conditions. Am. J. Enol. Vitic. 54(3): 143-149.

Seki, M., Kamei, A., Yamaguchi-Shinozaki, K., and Shinozaki, K. 2003. Molecular responses to drought, salinity and frost: common and different paths for plant protection. Curr. Opin. Biotechnol. 14(2): 194-199.

Serraj, R., and Sinclair, T. 2002. Osmolyte accumulation: can it really help increase crop yield under drought conditions? Plant Cell Enviorn. 25(2): 333-341.

Sheldrake, M., Rosenstock, N. P., Mangan, S., Revillini, D., Sayer, E. J., Olsson, P. A., \& Wright, S. J. 2018. Responses of arbuscular mycorrhizal fungi to longterm inorganic and organic nutrient addition in a lowland tropical forest. The ISME j. 12:10.

Sjöberg, J. 2005. Impact of AM fungi on crop nutrition. Arbuscular mycorrhizal fungi 32(8):430-456.

Smith, S., and Read, D. 2008. "Mycorrhizal symbiosis, 3rd edn. Academic". Elsevier, London.

Smith, S.E., and Smith, F.A. 2011. Roles of arbuscular mycorrhizas in plant nutrition and growth: new paradigms from cellular to ecosystem scales. Annu. Rev. Plant Biol. 62: 227-250.

Soka, G., and Ritchie, M. 2015. Arbuscular mycorrhizal symbiosis, ecosystem processes and environmental changes in tropical soils. Appl. Ecol. Environ. Res 13: 229-245.

Subramanian, K., and Charest, C. 2007. Arbuscular mycorrhiza and drought management of crops. Montano NM, Camargo Ricalde SL, Garcia.

Subramanian, K., Charest, C., Dwyer, L., and Hamilton, R. 1997. Effects of arbuscular mycorrhizae on leaf water potential, sugar content, and $\mathrm{P}$ content during drought and recovery of maize. Can. J. Bot. 75(9): 1582-1591.

Subramanian, K., Santhanakrishnan, P., and Balasubramanian, P. 2006. Responses of field grown tomato plants to arbuscular mycorrhizal fungal colonization under varying intensities of drought stress. Sci. Hortic. 107(3): 245-253.

Subramanian, K.S., Bharathi, C., and Jegan, A. 2008. Response of maize to mycorrhizal colonization at varying levels of zinc and phosphorus. Biol. Fertil. Soils. 45(2): 133-144.

Subramanian, K.S., and Charest, C. 1995. Influence of arbuscular mycorrhizae on the metabolism of maize under drought stress. Mycorrhiza 5(4): 273-278.

Subramanian, K.S., and Charest, C. 1997. Nutritional, growth, and reproductive responses of maize (Zea mays L.) to arbuscular mycorrhizal inoculation during and after drought stress at tasselling. Mycorrhiza 7(1): 25-32.

Subramanian, K.S., and Charest, C. 1998. Arbuscular mycorrhizae and nitrogen assimilation in maize after drought and recovery. Physiol. Plant. 102(2): 285-296.

Subramanian, K.S., and Charest, C. 1999. Acquisition of $\mathrm{N}$ by external hyphae of an arbuscular mycorrhizal fungus and its impact on physiological responses in maize under drought-stressed and well-watered conditions. Mycorrhiza 9(2): 69-75.

Subramanian, K.S., Tenshia, J.V., Jayalakshmi, K., and Ramachandran, V. 2011. Antioxidant enzyme activities in arbuscular mycorrhizal (Glomus intraradices) fungus inoculated and non-inoculated maize plants under zinc deficiency. Indian J. Microbiol. 51(1): 37-43.

Sylvia, D., Hammond, L., Bennett, J., Haas, J., and Linda, S. 1993. Field response of maize to a VAM fungus and water management. J. Agron. 85(2): 193-198.

Tisserant, E., Kohler, A., Dozolme-Seddas, P., Balestrini, R., Benabdellah, K., Colard, A., et al. 2012. The transcriptome of the arbuscular mycorrhizal fungus Glomus intraradices (DAOM 197198) reveals functional tradeoffs in an obligate symbiont. New Phytol. 193(3):755-769.

Tobar, R., Azcón, R., and Barea, J. 1994a. Improved nitrogen uptake and transport from ${ }^{15} \mathrm{~N}$-labelled nitrate by external hyphae of arbuscular mycorrhiza under water-stressed conditions. New Phytol. 126(1): 119-122.

Tobar, R., Azcón, R., and Barea, J. 1994b. The improvement of plant $\mathrm{N}$ acquisition from an ammonium-treated, drought-stressed soil by the fungal symbiont in arbuscular mycorrhizae. Mycorrhiza 4(3): 105-108.

Trenberth, K.E., Dai, A., Van Der Schrier, G., Jones, P.D., Barichivich, J., Briffa, K.R., et al. 2014. Global warming and changes in drought. Nat. Clim. Change 4(1): 17.

Turner, S.D., and Friese, C.F. 1998. Plant-mycorrhizal community dynamics associated with a moisture gradient within a rehabilitated prairie fen. Restor. Ecol. 6(1): 44-51.

van Kessel, C., Singleton, P.W., and Hoben, H.J. 1985. Enhanced $\mathrm{N}$-transfer from a soybean to maize by vesicular arbuscular mycorrhizal (VAM) fungi. Plant Physiol. 79(2): 562-563.

Veresoglou, S. D., Chen, B., \& Rillig, M. C. 2012. Arbuscular mycorrhiza and soil nitrogen cycling. Soil Biol. Biochem. 46: 53-62.

Vézina, L.P., Margolis, H., McAfee, B., and Delaney, S. 1989. Changes in the activity of enzymes involved with primary nitrogen metabolism due to ectomycorrhizal symbiosis on jack pine seedlings. Physiol. Plant. 75(1): 55-62.

Walder, F., Niemann, H., Natarajan, M., Lehmann, M.F., Boller, T., and Wiemken, A. 2012. Mycorrhizal networks: common goods of plants shared under unequal terms of trade. Plant physiol. 159(2): 789-797.

Watts-Williams, S.J., and Cavagnaro, T.R. 2012. Arbuscular mycorrhizas modify tomato responses to soil zinc and phosphorus addition. Biol. Fertil. Soils 48(3): 285-294. 
Wery, J., Silim, S., Knights, E., Malhotra, R., and Cousin, R. 1994. Screening techniques and sources of tolerance to extremes of moisture and air temperature in cool season food legumes, in Expanding the Production and Use of Cool Season Food Legumes. Springer, 439-456.

Yancey, P.H. 2001. Water stress, osmolytes and proteins. Am. Zool. 41(4): 699-709.

Yin, N., Zhang, Z., Wang, L., and Qian, K. 2016. Variations in organic carbon, aggregation, and enzyme activities of gangue-fly ash-reconstructed soils with sludge and arbuscular mycorrhizal fungi during 6-year reclamation. Environ. Sci. Pollut. Res. 23(17): 17840-17849.

Yooyongwech, S., Phaukinsang, N., Cha-um, S., and Supaibulwatana, K. 2013. Arbuscular mycorrhiza improved growth performance in Macadamia tetraphylla L. grown under water deficit stress involves soluble sugar and proline accumulation. Plant Growth Regul. 69(3): 285-293.

Zhu, X., Song, F., and Xu, H. 2010. Influence of arbuscular mycorrhiza on lipid peroxidation and antioxidant enzyme activity of maize plants under temperature stress. Mycorrhiza 20(5): 325-332.

Zhu, Y.-G., and Miller, R.M. 2003. Carbon cycling by arbuscular mycorrhizal fungi in soil-plant systems. Trends in Plant Sci. 8(9): 407-409.

Zou, Y.-N., Wu, Q.-S., Huang, Y.-M., Ni, Q.-D., and He, X.-H. 2013. Mycorrhizal-mediated lower proline accumulation in Poncirus trifoliata under water deficit derives from the integration of inhibition of proline synthesis with increase of proline degradation. PLoS One 8(11): e80568. 